\title{
This is not a game: testimony and the making and unmaking of the child as a political subject
}

\author{
JULIA EMBERLEY
}

In Canada in May 2006, Deborah Ellis's book Three Wishes: Palestinian and Israeli children speak became an object of controversy when the Canadian Jewish Congress protested its availability to junior elementary students in the Toronto school system. The Ontario Library Association (OLA) had nominated the book for its Silver Birch reading program. The books chosen for this program are not mandatory texts on the school curriculum. Rather, the program is designed to encourage children in grades four to six (nine-twelve year olds) to read recreationally. School libraries distribute Silver Birch books and the children who read them can vote at the end of the school year on their favourite fiction and non-fiction works.

Under pressure from the Canadian Jewish Congress, the Toronto District School Board restricted access to the book and removed it from school libraries serving children below grade seven. PEN Canada, an association of national and international writers that exists to protect, among other things, freedom of expression, the House of Anansi Press, the Canadian publisher of Three Wishes, and Ellis herself protested the decision made by the Toronto District School Board.

In an article from the Canadian Jewish News, Paul Lungen explained that

the OLA describes Three Wishes as allowing 'young readers everywhere to see that the children caught in this conflict are just like them, but living far more difficult and dangerous lives. Without taking sides, it presents an unblinking portrait of children victimized by the endless struggle around them.'

Critics, however, argue the book presents a uniformly negative image of Israel, provides little context for young readers about a conflict whose details are beyond their understanding, and introduces students to Palestinian youths who aspire to be suicide bombers and kill Israelis. ${ }^{1}$

1 Lungen, P. 2006, 'York school board pulls controversial children's book', Canadian Jewish News, 23
January 2006, accessed 17 February 2006, <http://www.cjnews.com/index.php?option=com_content\&task 
In addition, a teacher in the Toronto school system was quoted as saying that 'I didn't feel, and neither did the other teachers, that the children here have the knowledge to understand the difference between opinion and fact' ${ }^{2}$

The controversy over Three Wishes raises several important questions relevant to pedagogical issues and social policy about the kind of role educational institutions, political lobby groups, community and religious organisations, and book sellers should play in the regulation of extra-curricular reading practices for Ontario elementary school children. The oppositions of opinion and fact, the regulation of children who produce testimony and those who read it, and the targeting of children with or without the knowledge to comprehend the meaning of testimony or political conflict beg to be disentangled from one another. Also notable with regards to the controversy was how the politics of the debate straddled the 'rights' spectrum, from those in support of the right of free speech to those insisting on the right to participate in Canadian policy making on education as part of the multicultural grid work of 'Canadian society' - the latter clearly achieving its objectives here. ${ }^{3}$ In order to comprehend these competing human rights' discourses, it is important to reflect on how the controversy mobilised children as political subjects within a transnational framework of testimonial discourse. Of particular interest is how these competitive rights' discourses generate notions of childhood, fantasy and the meaning of the Palestinian and Israeli conflict in the Canadian context.

Three Wishes belongs to an increasing number of published books in the field of testimonial studies charged with endowing the child with the role of bearing witness to traumatic events. In so doing, the child as testifier is empowered to produce historical truth and authentic, realistic representations of events. In considering what enables this newly authorised voice, we need to address the contexts in which children testify. In what forms, for example, do children's testimonies appear and how are they circulated? Who authorises these 'minor' voices to appear in the public domain? And who listens, reads and responds to them? With regards to the child, there is also a specific theoretical problem to address, which is that of distinguishing between whether a child is testifying to a real event or just playing, in the sense of investing people, places and things with fears, fantasies and desires. In examining Three Wishes, therefore, the question of how the child is made a political figure in a transnational framework of testimonial production must also be open to the question of how the child has

+view\&id $=11161 \&$ Itemid $=86>$

2 Ibid.

3 Recent lobbying efforts announced by the Canadian Jewish Congress include 'participation in Royal Commissions on Hate propaganda in the 1960s and the prosecution of Nazi War Criminals in Canada in the 1980s, as well as significant input into Canadian policy-making on education, freedom of religion, and other human rights issues' (<http://www.cjc/ca/>). 
already been 'unmade', in the sense that the political subject positions opened up for children are already circumscribed and over-determined by specific cultural and discursive constructions of childhood such as innocence.

Ellis's collection of testimonial narratives provides an opportunity to explore how the shifting boundary between fantasy and reality contained within the testimonies informs the book's controversial reception. This shifting boundary is discussed further in this chapter in relation to Freud's study "'A child is being beaten"', 4 in which the modern conception of childhood emerges as a particular site of knowledge that privileges fantasies of violence over their physical realities and not just their physiological effects. The concluding section turns to the comic-strip novel by Marjane Satrapi, Persepolis: The story of a childhood. In this semi-autobiographical account of the Iranian religious coup in 1979, a child narrates her experience of repression and its effects on her, her family and her family's friends. By positioning, ironically, the child as narrator and by using the graphic, black-and-white comic-strip form, Satrapi redraws the lines between childhood innocence and the problem of ignorance and global responsibility in addressing violence towards children and youth.

By situating Ellis's book and the controversy surrounding it in the context of the modern ideal of childhood as a site of psychoanalytical knowledge, I argue that the possibility of children testifying to trauma and the violence of war is overdetermined by the production of competing fantasies about who or what lies at the origins of violence. From these competing fantasies emerge transnational complicities of innocence that disavow the narratives of trauma and wartime conflict as told by children.

The 1997 Italian film La Vita e Bella (Life is Beautiful) ${ }^{5}$ presents an exemplary text for working through the construction of 'childhood innocence' and the complicities of innocence under scrutiny in testimonial studies. The film is a tragi-comedy about an Italian Jewish man and his son who are sent to a Nazi concentration camp during World War II. The film mobilises the child as witness' to the Holocaust and it does so through a comic medium and the figure of the child's father, Guido, played by the film's director, Roberto Benigni. In a memorable scene, Guido pretends to 'translate' from German to Italian a Nazi corporal's death threats and commands for his son, Joshua, but when he does so he changes the text into a series of rules for how to play a child's game. The father appears to mediate his son's limitations as a witness by teaching him the correct way of comprehending the Nazi's words. While critics of the film might read this scene as the misguided transformation of fascism into a childhood

4 Freud, S. 1955-74, “A child is being beaten": a contribution to the study of the origins of sexual perversion', in James Strachey (trans.), The Standard Edition of the Complete Psychological Works of Sigmund Freud, Hogarth, London, vol. 17, pp. 179-204.

5 Benigni, R. (dir.) 1997, La Vita è Bella [Life is Beautiful]. US English dubbed version, 1998. 
game, there is, however, a deeper irony at work here. Through the trope of translation, the violence of fascism is mis-recognised as a children's game. Thus, due to his apparent innocence, Joshua is unable to read the signs leading to his father's death. It is one of the striking features of the film that Guido's death comes as a horrifying surprise. This reaction exposes the degree to which the audience has been unwittingly drawn into a similar state of innocence - or more accurately, ignorance-largely through Benigni's comic and childlike behaviour. The complicities of innocence explored in the film point to the desire to maintain a primary fantasy that no-one really dies. It's only a game. It's only a movie.

The criticism directed by the Canadian Jewish Congress and Toronto's educational authorities towards what elementary Canadian schoolchildren were capable of understanding about Three Wishes also engaged in similar complicities of innocence. As in a camera obscura, the children who testified in the book were projected through the narrow lens of such contemporary orientalist tropes as the Palestinian suicide bomber and the desire for martyrdom. The cultural subjection of these children and their childhood to such cosmopolitan fantasies effectively overshadowed any conversation that might have taken place concerning the testimonial texts given by Palestinian and Israeli children as witnesses to death and suffering in the Occupied Territories.

It is tempting to think about these children as representing a potentially new political constituency for whom it is hoped that political orientation, rather than religious or national identity, for example, might determine a future resolution to the so-called Middle Eastern conflict. Ultimately, however, the kind of pedagogical claims that can be made for children's testimonial practices in the teaching on 'war' in general or 'the Middle Eastern conflict' in particular is an open question. As is the question of what sort of transnational links between Canada and the Middle East can be forged in the circulation in the Canadian public domain of Palestinian and Israeli children's testimony in Three Wishes. We might ask, for example, what mode of globalisation circumscribes the textual relations between reality and fantasy in this book ${ }^{6}$ What are the political and social effects produced by the shifting boundaries of reality and fantasy in global digital media and in Three Wishes specifically? There will be no meaningful answers to these questions, however, if the rights of children to narrate their experience, what they see and what they know are subject to the censoring and self-censoring reactions of those who cannot and will not face the realities of death and suffering in children's lives 'here' and 'elsewhere'.

\footnotetext{
6 Along with the expansion of transnational capitalism during the late 1950s to the mid 1970s, cultural imperialism shifted dramatically in its modes of meaning production with the notable commodity expansion of technologies of representation such as film, photography, computers and other digital media. 'Globalisation' is a term that signifies this effect of a one-dimensional homogenisation of meaning and value and it is also the process of putting it into place - as if globalisation is inevitable and 'already in existence', as it were.
} 
The juxtaposition of the fairytale motif of 'three wishes' in the title of Ellis's book with the testimonial speech acts of Palestinian and Israeli children seems somewhat incongruous, but as Ellis writes: 'I asked the children I met to tell me about their lives, what made them happy, what made them afraid and angry, and how the war has affected them. They told me about their wishes for the future. ${ }^{7}$ The notion of desire at work here confers what Wafaa Hasan notes as the limited but consequential 'authorial agency' on the children in this text. ${ }^{8}$ The engineers of the controversy, however, symptomatically reproduced, rather than called into question, this neo-liberal and post-colonial regime of representation.

How we situate the war on phantasms and 'phantom' war in relation to the 'real' war between the occupied Palestinian territories and the State of Israel might be considered by drawing out the complicities of innocence currently associated with the testimonial construction of childhood and the meanings attributed to children's testimonial narratives. In other words, while the arbiters of public virtue do boundary maintenance work on the Fantasyreality Line ${ }^{\mathrm{TM}}$ another sort of 'war' is taking place in the field of representation between political and commodified re/presentations of children and childhood. Take a Ride on the Reading. Do Not Pass Go. Do Not Collect \$200 (CAN). The 'monopoly' on the meaning of children's reality is, however, far from a childhood game. Rather, it is a 'game' of borders that is being re-enacted by the debate, a game that involves policing the boundary between fantasy and reality as a way of securing property rights in the Occupied Territories, for example. Before exploring further the fantasy/reality divisions embedded in the debate and the book, I want to take a detour along the Fantasyreality Line ${ }^{\mathrm{TM}}$ by excavating Freud's study "'A child is being beaten"'. The modernist use of fantasy in Freud's construction of childhood, I argue, serves to regulate, as well as introduce, self-regulatory mechanisms for the control of the affective modes of desire, love, longings and violence in the figure of the child.

\section{A child is testifying, or, taking a ride on the Fantasyreality Line ${ }^{\mathrm{TM}}$}

Sigmund Freud took the production of fantasy seriously in the early twentieth century at a time when the French and the English were busy redrawing the cartography of the Middle East through the Sykes-Picot Accord (1916) and the Balfour Declaration (1917). Freud's work is also relevant because - as readers familiar with the field of literature and trauma studies are aware - the

7 Ellis, D. 2004, Three Wishes: Palestinian and Israeli children speak, House of Anansi Press, Toronto, p. 9.

8 Hasan, W. 2008, 'The politics of childhood in Ellis's Three Wishes', CLCWeb: Comparative Literature and Culture, vol. 10, no. 2, accessed 28 February 2009, <http://docs.lib/purdue.edu/clceb/vol10/iss2/4> 
approach to the field has been dominated, not surprisingly, by psychoanalytical theories and methods. ${ }^{9}$ My interests here, however, lie in developing other methodological approaches that attend to the material limits of the production of meaning and include psychoanalytical discourses as one of those limits rather than as an analytical trajectory for the study of the texts at hand.

While the bond between testimony and psychoanalysis might help to avoid the disciplinary mistake that occurs when the telling of life stories is presented as equivalent to historiography, psychoanalytical discourse creates its own problems when it disavows material reality in favour of fantasy as the basis for producing pathology. Fantasy is essential to psychoanalytical discourse and its transcendence of historical events. In order to establish the key role of fantasy over the problems of conflicting interpretations of reality, however, fantasy is positioned as supplemental to knowledge in Freudian discourse. Freud has his own interests in view when he uses the work of fantasy to discipline potential disciples of psychoanalysis. At the same time, I would argue, his disciplinary formation of psychoanalysis constitutes a form of epistemic violence that not only disciplines the agent of psychoanalytical discursive production, it sacrifices 'childhood' to knowledge by circumscribing the claims to truth that can be produced. Childhood constitutes a specific time that can best be retrieved through the memorialising practices of psychoanalytical intervention. As a result of this disciplinary and disciplining formation, the value of fantasy for the institutionalisation of psychoanalysis as a scientific discourse supersedes the real needs of the human subject for justice and healing. Nevertheless, even Freud must acknowledge that within the fantasy productions of childhood the seeds of an original experience recounted by someone, somewhere exist and point to a real event. It is the trace of this original experience that psychoanalytical testimony must manage if it is to maintain the epistemic hegemony of the science of psychoanalysis. If, however, we read this 'trace' as a residue of something productive for the subject we might begin to plot a different story about childhood - one that interweaves the conflicting experience of reality with the healing mechanisms of fantasy.

The epistemic basis for examining a child's fantasy of violence in relation to the reality of his or her sexual development is provided for by Freud's study "'A child is being beaten"'. Freud's study distributed the coordinates of childhood

9 See, for example, Aberbach, D. 1989, Surviving Trauma: Loss, literature and psychoanalysis, Yale University Press, New Haven, Conn.; Britzman, D. 1998, Lost Subjects, Contested Objects: Toward a psychoanalytic inquiry of learning, State University of New York Press, New York; Felman, S. and Laub, D. 1992, Testimony: Crisis of witnessing in literature, psychoanalysis, and history, Routledge, New York; Caruth, C. (ed.) 1995, Trauma: Explorations in memory, The Johns Hopkins University Press, Baltimore; Caruth, C. (ed.) 1996, Unclaimed Experience: Trauma, narrative, and history, The Johns Hopkins University Press, Baltimore; LaCapra, D. 1994, Representing the Holocaust: History, theory, trauma, Cornell University Press, Ithaca; LaCapra, D. 1996, Writing History, Writing Trauma, Cornell University Press, Ithaca; LaCapra, D. 1998, History and Memory After Auschwitz, Cornell University Press, Ithaca 
along the lines of the Real and the non-Real, the latter circumscribed by such terms as 'memory', 'fantasy', the 'unconscious', 'play', 'spirit' or 'imagination'. One of the key articulations in the field of representation that circulated in the general economy of infantilisation during the early twentieth century included the child as savage - a configuration that was produced by and maintained in the sedimentation of European imperialism. ${ }^{10}$ The mutually interrelated, however distinct, figures of the savage child or the childish savage preserved the child's body as an object of violence, desire and narrative investments in the domestication or the taming of a wild, untempered, pre-oedipal, semiotic flux.

Freud's study of oedipalisation - what he calls 'love' in "AA child is being beaten"'-represents a key moment in the use of modern institutional and epistemic violence to rewrite the residual materialities of economic and political power in terms of the knowledge of the Real as distinct from the non-Real such as fantasy. Freud's method of policing a child's relationship to the domain of the Real involved constituting non-Reals as insubstantial or immaterial aspects of everyday experience. Non-Reals or non-realities, however, were once tangible and visibly concrete materialities that could have existed as a vestigial materiality or as an emerging and potentially new materiality. The line between the material and immaterial is therefore not as fixed as it appears; additionally, the problem of regulating the unstable relationship between the material and the immaterial calls attention to the materiality of signification, in which even when an apparent 'reality' seems to be outside language or symbolic codes this is precisely what gives the apparent immateriality of the signification of 'fantasy' an illusive and mystical power, which, if it is to have any purchase in the domain of science, must be embodied in or transmitted by a representative, authoritative figure of knowledge such as a rabbi or a priest, a scientist, a professor or a father.

In "'A child is being beaten"', Freud makes reference to real physical violence but ultimately displaces it into a fantasy of violence. In order to displace the reality of material violence, Freud puts into play a discursive method based on the coercive use of reason with which to establish institutional forms of authority such as the psychoanalyst or the father. Freud acknowledges that the sentence 'a child is being beaten', although a fantasy, could be written on the basis of an experience of 'real corporal violence', ${ }^{11}$ specifically with reference to children who witnessed the very common use of the rod in the early twentieth century in disciplining schoolchildren:

10 Further to this point, see Emberley, J. 2007, Defamiliarizing the Aboriginal: Cultural practices and decolonization in Canada, University of Toronto Press, Toronto (especially pp. 91-115), in which I discuss, in Freud's Totem and Taboo, for example, the production of the varied deployments of the infantilised figure of the Aboriginal.

11 Freud, "'A child is being beaten"', p. 181. 
When the child was at school and saw other children being beaten by the teacher...The influence of the school was so clear that the patients concerned were at first tempted to trace back their beating-phantasies exclusively to these impressions of school life, which dated from later than their sixth year. But it was never possible for them to maintain that position; the phantasies had already been in existence before. ${ }^{12}$

Freud's knowledge of the fantasy of a child being beaten beyond the sixth year is limited by the fact, he writes, that 'the impressions that brought about the fixation were without any traumatic force. They were for the most part commonplace and unexciting to other people. ${ }^{\prime 3}$

The fantasy of being beaten presents Freud with a number of contradictory elements: the displacement between childhood memories of school life and the fact that the fantasy begins earlier than real experience would or could provide empirical proof of; the contrary registers of child beating are, in reality, 'traumatic' and yet, during the psychoanalytical investigation, the limits of knowledge are tested by the cause of the fantasy being a non-traumatic - that is, non-violent - impression. Freud establishes in his analytical framework a set of relations among knowledge, trauma (that is, violence) and fantasy. Within this framework, reality and memory are set at odds to each other; 'reality' is represented as a determinate fact locatable in the educational context and 'memory' is viewed as indeterminate, without a precisely locatable context (for example, a vague impression of an event). This conflict between the site of the production of knowledge and the everyday productions of traumatic fantasies constitutes for Freud the basis of the pathology of sadomasochistic repression.

What lies at the centre of this conflict is the problem of competing origin stories: the double origins of, on the one hand, memory's first light and, on the other, the analytical remembering of a 'reality'. The latter form of remembering emerges in the process of recounting a series of events that can be shaped to the oedipal narrative. It is only on the basis of the oedipal narrative that the psychoanalytical cure becomes possible. The struggle between these two origins is, in part, a struggle between the materiality of the body and Freud's disciplining of the subject and text of psychoanalysis. Pathology excoriates the father's disciplining of the child-with the rod, the stick, the cane, the case study, the phallus. Parental and pedagogical authority, as forms of power over the production of the child's text and its meaning, are not questioned.

Reading the conflict of origin stories from a discourse-materiality perspective allows for the possibility of rethinking the question of the sentence 'a child is being beaten' as an instance of the hysterical child's alienation from her own history and body - an alienation that is the subject-effect of the power of identity making: to make the child in the image created by the father, not the image

12 Ibid., pp. 179-80.

13 Ibid., p. 182. 
'of' the father, but the father's image, his making, unmaking, reproduction and re-presentation. Competing narratives between the father's identity un/making and the mother's subject making are also at stake in the struggle between dual origin stories. Here is an example of Freud's born-again rhetoric:

The origin of the Oedipus complex itself, and the destiny which compels man, probably alone among all animals, to begin his sexual life twice over, first like all other creatures in his early childhood, and then after a long interruption once more at the age of puberty - all the problems that are connected with man's 'archaic heritage' - have been discussed by me elsewhere, and I have no intention of going into them in this place. $^{14}$

The moves from animal to human, ignorance to knowledge, nature to culture, mother to father, primitive to civilised (outlined in his Totem and Taboo), ${ }^{15}$ account for the need for the dual origins of Man, born first into the immateriality of fantasy and ignorance - notably the bond with the mother - then into material culture and knowledge. That Freud takes time - the first six years of a human's life - as the site of the psychoanalytical narrative construction of the oedipal self is very telling: it is a time little remembered, a time of ap/parent 'loss'. It is therefore the role of the psychoanalyst to reconstruct this elusive period:

Strictly considered - and why should this question not be considered with all possible strictness? - analytical work deserves to be recognized as genuine psycho-analysis only when it has succeeded in removing the amnesia which conceals from the adult his knowledge of his childhood from its beginning (that is, from about the second to the fifth year). This cannot be said among analysts too emphatically or repeated too often. The motives for disregarding this reminder are, indeed, intelligible. It would be desirable to obtain practical results in a shorter period and with less trouble. But at the present time theoretical knowledge is still far more important to all of us than therapeutic success, and anyone who neglects childhood analysis is bound to fall into the most disastrous errors. ${ }^{16}$

Freud plays with the authority of his own disciplinary rod of reason when he says 'strictly considered - and why should this question not be considered with all possible strictness?'. ${ }^{17} \mathrm{He}$ is, of course, in the business of creating disciples in the newly emerging field of psychoanalysis. He disciplines his student child-analyst and tells him what is appropriate to observe and how important it is to remove the 'amnesia' from the adult subject's knowledge of his childhood. Let's hope the disciples don't forget that this is their job. These crucial years in which memory

\footnotetext{
14 Ibid., p. 193.

15 Freud, S. 1927, Totem and Taboo: Resemblances between the psychic lives of savages and neurotics,

A. A. Brill (trans.), New Republic Inc., New York.

16 Freud, "A child is being beaten"', p. 183.

17 Ibid., p. 183.
} 
is apparently lost are returned to the subject fully explained and articulated through the analyst, perhaps in the same way the clerics interpreted the Bible for the illiterate before the European Reformation. But the rise of literacy among European children and the compulsory Education Acts of the nineteenth century in England, for example, meant that it was becoming increasingly difficult to locate a European subject who could not read or write for her or himself. Nevertheless, Freud found a period in childhood over which to assert his oedipalnarrative authority. The adult is thus born into the 'long interruption' in which the maternal force is dominant and then reborn under an oedipal and patriarchal narrative construction. The subject is, indeed, made through the sacrificial coercion of bio-graphy and the narrative always concludes in the same way: with the incestuous love of the (female) child for the father. This love is, however, always already violent: 'There can be no doubt that the original phantasy in the case of the girl, "I am being beaten (i.e. I am loved) by my father", represents a feminine attitude. ${ }^{\prime 18}$ To be beaten in reality is to be loved (like a woman) in fantasy.

Whether the children are being beaten or not 'in reality' is not the only issue here. There is also the fact that their life story is narrated as one in which they have already been victimised by their own desires. It is the authorisation of their life story as a contractually agreed on story of victimisation that is enough to constitute them as subjugated and in need of the governing rationality of institutional authorities. The sort of counter-memorialisation that can take place in testimonial narratives is, of course, as much a strategic construction as psychoanalytical memorialisation and it is one that is directed towards dismantling the institutional powers of authority. When one claims one's memories as one's own, for example, institutional powers of authority are significantly challenged, if not displaced. This is why 'testimonial narratives' can make important interventions into the authoritative mediations of cultural knowledge. As noted in the case of Three Wishes, however, testimonial narratives can also be subject to the institutional regulation of their distribution and significance, to problems of 'fantasy' and 'reality' that displace the material realities of suffering, exploitation and oppression, not to mention physical violence and violent forms of death.

On the one hand, Freud's modernist turn towards fantasies of violence promoted forms of self-regulation or self-censorship when it came to monitoring forms of physical violence. On the other hand, the focus on childhood fantasy, especially as a locus of knowledge, meant that the fantasy/reality opposition became a never-ending point of contention. It is one, however, that can be reconsidered, by focusing on competing fantasies and the cultural forms in which competing fantasies play themselves out. In testimonial discourses today, there is an increasing turn towards the construction of the child as witness and attention to memory as a site of childhood trauma. This turn towards the child extends the modernist problem of the child as a semi-autonomous subject attached to 
multiple institutional organs from the family to the school, from the State to its child-welfare agencies. It also opens up new contingencies of truth, power, representation and knowledge. In the next section, I return to Three Wishes in order to explore further the competing fantasies of 'the martyr' and 'the suicide bomber' and how these competing fantasies become the very basis for censoring the text and disavowing its testimonies of suffering and death.

\section{Transnational imaginaries (?)}

Each child in Three Wishes articulates his or her own desire to transcend the current predicament in which they find themselves: impoverished, dehumanised, demoralised and living with the constant fear of death for the Palestinian children, and living with the constant fear of violent interruption of an otherwise privileged daily life for the Israeli children. This latter situation generates fantasies of victimisation - notably the figure of the 'Palestinian terrorist' who is out to get them. There is no question about the psychological complexities of the children represented in this text, but any examination of them must be articulated with a critical account of the institutional forces and regulatory techniques that overdetermine the cultural production of fears and fantasies in the figure of the child.

The fantasy that gives the critics of Three Wishes the most trouble is that of a young Palestinian girl's desire to become a martyr. Salam, a twelve-year-old girl whose photograph is not included, gives the following testimony:

Aayat's [Salam's sister's] picture is everywhere, on walls and in newspapers. She is very famous. She is a martyr and is now in paradise, where it is supposed to be very beautiful. I would like to join her there. I would have to become a martyr like her, to be able to be in paradise with her.

When I see her again in paradise, I will ask her why she didn't tell me her plans.

I don't think it would hurt if I blew myself up. I don't think it hurt my sister. I think she was very brave, not scared at all. I think she was probably very happy.

I don't know if the girl she killed had a sister my age or not. What does it matter? I don't know any Israeli kids. Why would I want to? ${ }^{19}$

It is in reference to this passage that an anonymous source in Lungen's article is quoted as saying: 'One child talks about being a martyr. Is that what we want our children to be reading about?'20

19 Ellis, Three Wishes, p. 101.

20 Lungen, 'York school board pulls controversial children's book'. 
Testimonials by the Israeli children also engage in creating fantasies. For example, Merav, who is thirteen and lives in a settlement near Efrat, says:

If you wander around on your own, a Palestinian with a gun might see you and shoot you. They wait to catch people who are not being careful, who are thinking of other things and not watching out. You can only relax if someone is there to watch out for you. ${ }^{21}$

The production of the fantasy of the 'Palestinian with a gun [who] might see you and shoot you' is a moment in the testimonial text where fear is fuelled by a terrifying phantasm, where a virtual 'suicide bomber' might emerge anywhere and at any time to set off a real bomb. The phantom bomber remains, however, as an unexplained presence there to disrupt birthday parties, school outings or shopping sprees.

Ellis's text produces and unsettles a line between fantasy and reality, creating conditions in which the reader must make sense of the phantoms of terror in the paranoid fantasies of everyday life in Israel and the mystification of martyrdom and the desire for death in the occupied Palestinian territories. The fear of the phantom suicide bomber on the part of the Israeli girl Merav and the desire to become such a martyred phantom, or indeed a 'ghost', on the part of the Palestinian youth Salam represent contradictory and competing fantasies in Three Wishes. This contest over which phantom will be deployed and for what purpose triggers the very problem that will be symptomatically rehearsed in the controversy over the book when critics put forward a virtual Canadian readership to override the text's real testimonial content.

Ellis's collection of children's testimonies from the Middle East tells us about the psychic costs that occur when reality ruptures the appearance of external certainties and creates new and sometimes self-destructive longings in the face of the only known certainty, which is death. In both cases, waiting for death, in all its torturous passivity, is exceeded by a trip on the Fantasyreality ${ }^{\mathrm{TM}}$ Line, where the active and imaginative creation of a transcendental figure of absolute destruction (the martyr/the suicide bomber) emerges as the ideal saviour and deliverer of death.

The problem therefore becomes one of competing fantasies that are manufactured, commodified and recycled even by such a reparative text as Three Wishes. These competing fantasies are produced through chains of substitution-martyrs, terrorists, phantoms - in order to secure lines of contact and dissociation among Palestinian and Israeli children, on the one hand, and Canadian and Middle Eastern children, on the other, with all the hyphenated permutations in between. In the final section of this essay, I consider a different approach to these competing fantasies of ontological victimisation, in Marjane Satrapi's graphic novel Persepolis: The story of a childhood.

21 Ellis, Three Wishes, pp. 66-7. 


\section{Redrawing the lines}

Satrapi's graphic novel redraws the line between political and cultural representations. Persepolis opens up the question of 'representation' as a site of the political contestation itself.

Persepolis can be read as, among other things, an allegory of the changing materialities of 'dialectical materialism'. For example, Satrapi takes the principle of dialectical materialism (that is, history is the product of class struggle) as an instructional diagram and redraws its significance through the techniques of graphic narration. Not surprisingly, this graphic alteration generates a new diagraphein that draws attention to the materiality of the historical text - the fact that the so-called 'Islamic Revolution' is, for example, a visual or textual event dominated by certain forms of re-presentation and countered by others. While the materiality in the traditional definition of dialectical materialism resided in the male labouring body and its occupation in the class struggle, the diagraphein in Persepolis points to different materialities, including: technologies and techniques of visual or graphic representation, desire and the engendering of the female body, and the spatial organisation of meaning. Bodies, spaces and texts constitute new materialities that hold together a network of oppositions such as corporealities and incorporealities, territorialisations and de-territorialisations, significations and de-significations.

The central conflict in the rise of the Iranian Islamic regime, as Satrapi represents it, lies between religious fundamentalism and socialism. This antagonistic relationship is produced visually in the text in Satrapi's satirical use of the blackand-white simplicity of the cartoon or comic-strip format. Her graphic use of black and white is, however, carefully articulated in the frames where black serves as the outside environment with people represented as white and white serves as the inside of the home with people filled in in black. In the following discussion of Persepolis, I want to focus on the interplay between the graphic use of representational technologies and the grammar of images positioned on the page. Persepolis sketches a traumatic historical event in which the femaled body collapses under the threat of rape and death during the Iranian struggle.

The opening chapter initiates the reader into the highly fashioned symbolism of the veil that takes place during the Islamic takeover in 1979. The second frame contains a class photo of identical-looking girls. Five and a half girls appear in the frame wearing the headscarves that have become mandatory in schools. A de-personalised figure is created when the cartoon frame abruptly cuts off the image of the sixth girl. What might have been a token of personal experience, such as a school photograph, becomes not just a sign of the loss of the individual experience, but rather the emergence of the new female Iranian citizen. In the next frame, the schoolyard games of the children mockingly transform the remnants of individual experience into sadomasochistic exchanges between masters and slaves: 'execution in the name of freedom' (see Figure 1). Clearly, this is not a conventional 'children's book'. 


\section{- THE VEIL}
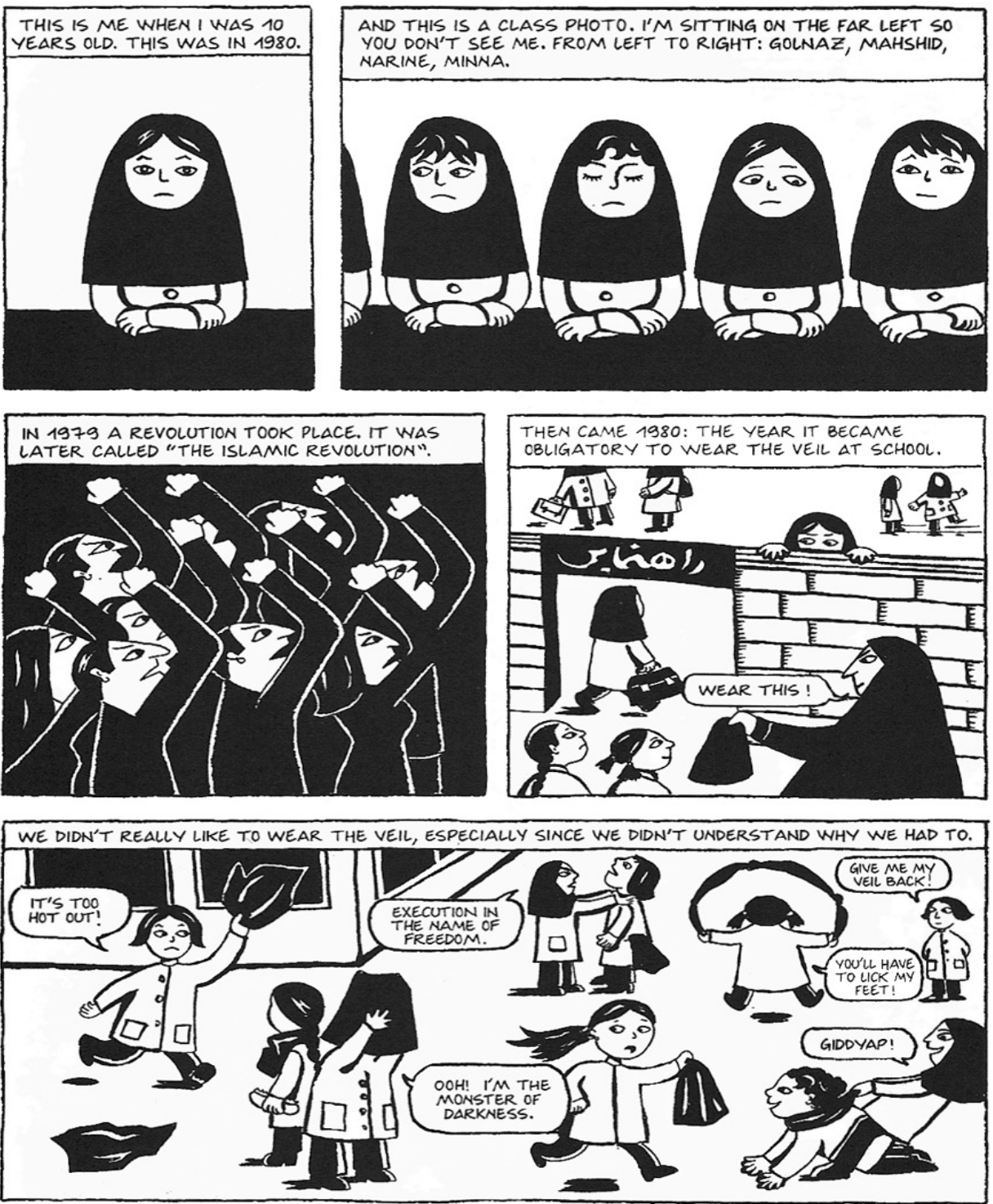

Pedagogical practices undergo other changes. What was once a secular praxis for intellectual development and learning changes into a disciplinary regime for the making of the new national citizens of Iran. Under Islamic rhetoric, bilingual schools become 'symbols of capitalism...of decadence' ${ }^{22}$ and the children are,

22 Satrapi, M. 2003, Persepolis: The story of a childhood, Pantheon, New York, p. 4. Originally published in France in two volumes in 2000 and 2001 respectively, by L'Association, Paris. 
therefore, divided into Christian and Islamic schools. This religious distinction also catechises the Islamic female child into existence, as she is disciplined into a spectacle of submission by having to wear the veil. The intertwining of religious and gender differences provides the basis for citizenship candidacy in the new Islamic State.

While the symbolic value of the veil draws attention to the limits of the political struggle in Iran, it is a photograph of Marji's mother protesting the veil and published in all the European newspapers that jeopardises her mother's life. The conflict over the symbolic meaning of the veil is represented by the narrative attention given to photographs within the graphic frame of the comic-strip format. This layering of representational techniques and their technologies produces the diagrammatic tension between the forces of political and cultural representation. Both modes of re/presentation are figured by different modes of visual materialisation: the photograph as 'political evidence' and the cartoon as its cultural framework of intelligibility. The Rex Cinema massacre, referred to in the next chapter, titled 'The Bicycle', is another event in which Satrapi dramatises a collision between the antagonistic forces of cultural and political representation. Moviegoers were locked inside a cinema that was purposely set on fire. Police 'forbade people to rescue those locked inside' and the 'firemen didn't arrive until forty minutes later. Four hundred people died, according to the BBC and the Shah blames "religious fanatics", although everyone knows it is his doing.' Political satire is evident in Satrapi's text, in which, in order to disarm the illusions of power and authority, the narrative voice of the child is permitted to say the unsayable.

Satrapi satirises the dialectical image in her juxtaposition of 'God' and 'Marx', where the mutual simulations of their authority are drawn in such a way as to bear an uncanny resemblance to each other (Figure 2).

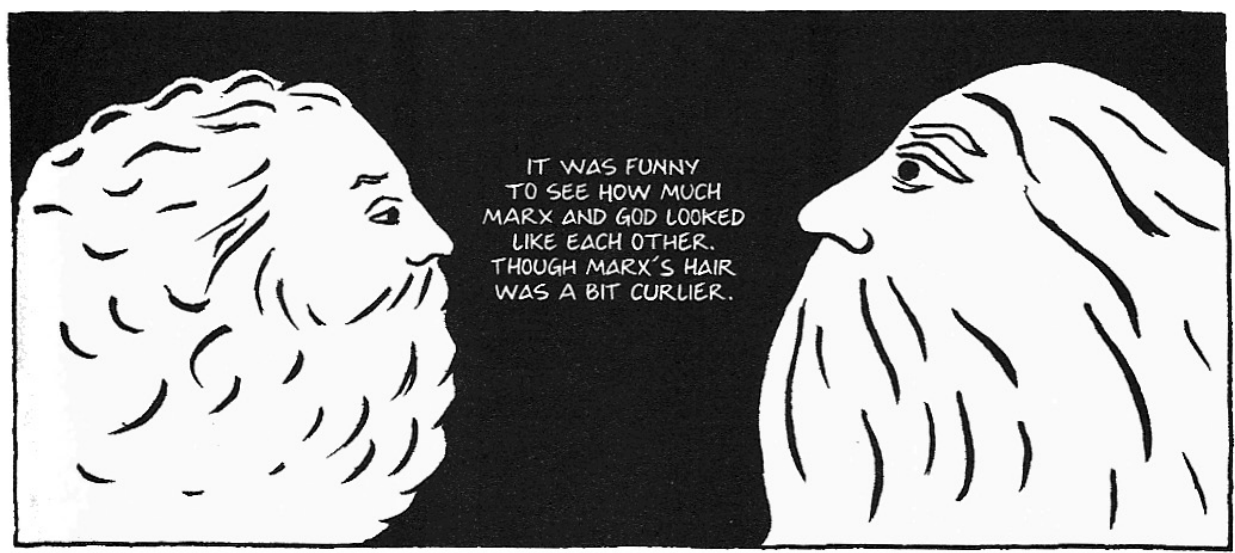


The cartoon book that sought to popularise Marx for the masses in Mexico, Marx para Principiantes, translated into English as Marx for Beginners, is playfully incorporated into the text..$^{23}$ Marji, the child narrator, reads the cartoon in her studies of Marxism, once she has abandoned her religious phase and desire to be a prophet. The education Marji receives at home begins to show signs of differing from her official education. This is a major theme in the story. Marji's increasing tension with educational authorities is one of the motivations for her leaving Iran to continue her education in Austria and then France at the conclusion to the narrative.

One of the first pedagogical lessons the reader, along with Marji, receivesnotwithstanding the lesson in Marxism and historical dialecticism disguised as the naive intellectual undertaking of a child - is a history lesson from her father on the political struggles of Iran. This history lesson also includes her family history, as Marji learns that her great-grandfather was overthrown by the Emperor Reza, who was supported by the British in their bid to capture Persia and its oil reserves before the Bolsheviks gained power in the territory in the early twentieth century. We also learn that Marji's grandfather eventually became a communist. The nationalist history of Iran follows with the title chapter, 'Persepolis'. In this chapter, the reader learns from Marji's grandmother about the symbolic significance of Persepolis as the mythic foundation of the Persian Empire and how the Emperor Reza re-enacted the spectacle of Persepolis in order to secure its symbolic power for an emerging modern Iranian nation. The spectacle of Persepolis as a myth of power is juxtaposed in the visual field with photographs taken by Marji's father at a demonstration in order to record and witness the political conflict: 'He took photos every day. It was strictly forbidden, he had even been arrested once but escaped at the last minute. ${ }^{24}$

While the spectacle dominates the visual field of representation, photographic images of political strife are criminalised and hidden from view, and yet both appear equally proportioned in the comic-strip frame. The scaling down of the spectacle, and the drawing of illicit photos, reconfigures the political value of the respective images. It is at the conclusion of this chapter, when a dead man's body becomes confused with the death of a political protestor, and, thus, a source of ironic humour, that the visual field becomes complicated by a multiplication of unstable identities, meanings and consequences. Not only is the visual field complicated by the indeterminacies of the meaning of this dead man's body, in the next chapter, titled 'The Letter', the political scope of Marxism is tested and complicated by Marji's relation to the family's maid, Mehri.

23 Ibid., p. 12.

24 Ibid., pp. 28-9. 
'The Letter' exposes the gendered contradictions of class politics in the domestic sphere and its regulation of Mehri's sexuality as well as her political authority in the public sphere. Although Marji points out with a self-conscious sense of embarrassment the fact that her father drives a Cadillac, it is the interception of Mehri's love letters to a neighbouring young man that brings the contradiction to its breaking point. Mehri ostensibly pretends to be Marji's sister and, because she is illiterate, has Marji write a love letter to the boy. Out of jealousy for Mehri's love for this boy, someone snitches on her and, on Marji's father discovering this narrative escapade, exposes Mehri to the neighbouring boy as merely 'the maid'. Mehri came to Marji's family when she was ten years old because her family had 15 children and couldn't afford to feed her. At the conclusion of this chapter, Mehri and Marji are punished for going together to a political demonstration - the notorious 'Black Friday' when hundreds of people are killed. They are both slapped across the face and the burning marks of these facial slaps are left engraved on their faces in the final frame of the chapter. Mehri is denied the fulfilment of her desire in love and in politics. If the letter does not reach its destination, it is not simply because of an indeterminacy of meaning, but rather the result of class power that can no longer be understood simply in terms of 'class' without also recognising the gendered mediation of its positions.

After the meaning of Mehri's love letter is opened up to the over-determinations of patriarchal class politics - and Mehri and Marij are exposed to physical violence - the conflict between the repressive regime of the Shah and the struggle for socialism is no longer a secure project for the dialectical unfolding of the material contradictions of reality. For Marji, it is the sexual politics of everyday life and her family's violent treatment of Mehri's political involvement that exposes the limits of socialism. It also unleashes the question of the impossibility of justice for women under a Marxist or Islamic regime of power.

In the post-Marxist narrative space of Persepolis, the social antagonism between ideological factions collapses into violence, massacres, executions, the unlimited use of young male bodies as fodder in the war with Iraq and the threat of death and rape to Marji and other young women who do not submit to Islamic law. One way to read this narrative is to note a developmental shift from 'ideology' to the administration of the violence of power. Another way is to read Mehri's situation and the violent regulation of her sexuality and political practices as an already existing site of the violence of power that the ideology of dialectical materialism helps to contain and disavow. The rupture of violence in the public form of political struggle symptomatically rehearses the violence of everyday life for women and children. 
The violent constitution of the 'self' in the name of the 'nation' that disavowed class segregation was, on the one hand, the alibi of the Islamic 'cultural revolution'. The violent constitution of the counter-self in the name of a socialist revolution that disavowed the gendering of class segregation was, on the other hand, yet another political alibi.

There is a further image juxtaposition I want to mobilise in Satrapi's text for the purposes of explicating the above comments and comparing it with Ellis's testimonial format. It is the following two frames (Figure 3).

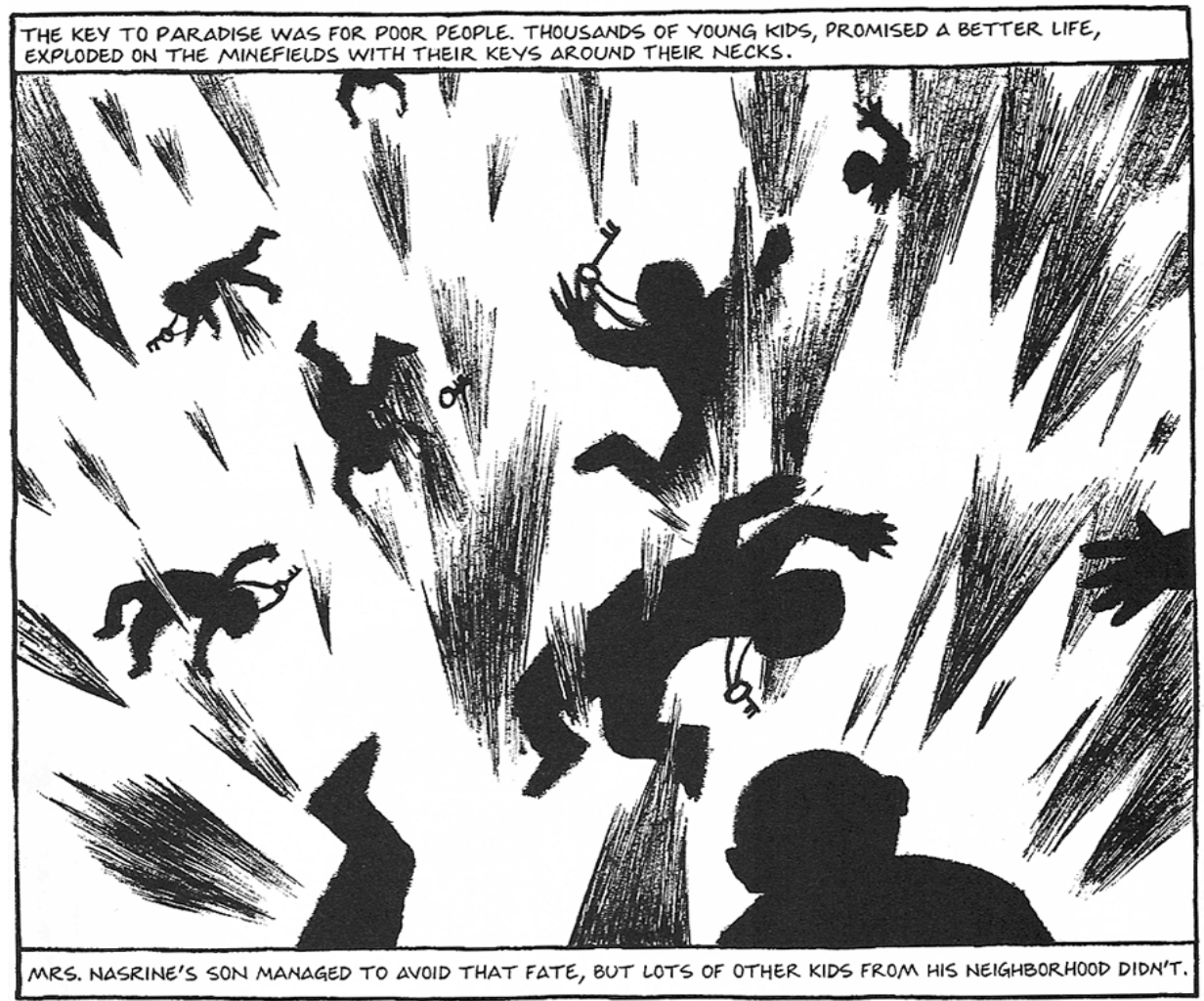

MEANWHILE, I GOT TO GO TO MY FIRST PARTY. NOT ONLY DID MY MOM LET ME GO, SHE ALSO KNITTED ME A SWEATER FULL OF HOLES AND MADE ME $\triangle$ NECKLACE WITH CHAINS AND NAILS. PUNK ROCK WAS IN.

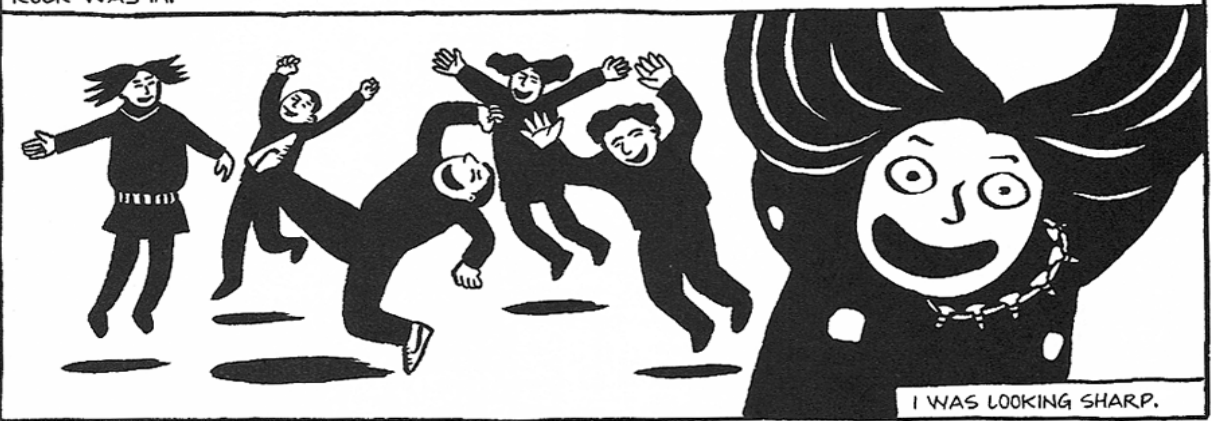


The juxtaposition of the subject of martyrdom, on the one hand, and a birthday party, on the other, uncannily mimics the passages I cited earlier from Three Wishes, in which the Palestinian and Israeli children are also distinguished by their positions within similar scenes. In Persepolis, however, the divisions between poor boys who become martyrs and middle-class Iranian youths enjoying a party are ones of class and male gendering. It is this analytical framework of the internal contradictions of the nation and how those contradictions are gendered in relation to poor male and female bodies that distinguishes Persepolis from Three Wishes. The simple binary 'ideological' logic of a Marxian dialectical materialism collapses in the wake of a complex network of contingencies that cuts across class, religion and gender. In Satrapi's representation, the bodies being blown towards a heavenly paradise, where boys are promised all the women they can possibly desire, and those of the dancing punks on Earth appear remarkably similar - the one appearing to overdetermine the other. They are not, however, simply 'similar', but rather subject to a similar set of interrelated contingencies involving class, gender and age differences.

In the final image of the first volume, Marji's mother has collapsed and her body is being held in the arms of Marji's father. Marji sees this because she turns around to have one last look at her parents before departing Iran for Austria. She must leave because it is getting too dangerous for her, particularly at school and in the street. Marji must leave Iran because if she does not leave now, at the age of fourteen, there is every indication that her political beliefs will result in her arrest and execution. Since, under Islamic law she cannot be executed as a virgin, she will be 'married' off (that is, raped) and then executed. These are the historical realities of a politics of vulnerability, youth and innocence.

In all three examples-Three Wishes, "A child is being beaten"' and Persepolis - questions about where 'education' can and does take place and for whose benefit are central to the formation of children as political subjects under globalisation and in their respective national imaginaries. The disciplinary force of Freud's psychoanalytical objectives through which he displaces the violent use of the rod in schools and the control over the readership of Three Wishes by the political lobby group the Canadian Jewish Congress demonstrate that the institutionalisation of education throughout the twentieth and twenty-first centuries has been and continues to be regulated by specific forms of epistemic violence. This pedagogical-epistemic violence includes the use of knowledge to coerce the child, similar to the ways in which the student of psychoanalysis is disciplined into the subject-hood of a male-centred and male-dominated oedipal framework to the exclusion of women and female children as producers and consumers of self and knowledge. This violence is also constituted by the use of formal educational institutions as sites in which to construct a national imaginary through the location of fantasy in the notion of 'childhood'. This last 
is especially important because it is through the notion of 'childhood' that the national imaginary is constructed and legitimated on the basis of a model of development and growth that mimics the advance of the nation economically and politically. Herein lies the significance of the child for the birth of the nation, as a political subject and as the repository of childhood.

Formal educational institutions are also used to rationalise political beliefs, whether in the context of Canada, Iran, the Palestinian Territories or Israel. Persepolis, however, takes us into the realm of multiple and counter-educational contexts such as the influence of adults in the home, children's games in the schoolyard, political demonstrations in the street, as well as the products of popular culture such as the rock music of Kim Wilde, featured in Persepolis, and, of course, comic books. In Persepolis, education is produced in a variety of 'non-educational' places; although the educational institution might still be a site of education as justice, it is so only in spite of itself in post-1979 Iran. Even the repressive mandate of the institution, however, can be deployed for 'educational' purposes.

There are no guarantees about what events, within what places or under what specific political and social conditions the making of critical knowledge might occur. Creating the all-knowing child, as Ellis does, however, or deploying the modern undeveloped child in need of the guidance of Freud's science of the self appears insufficient to address the current dilemma of children in today's globalised and militarised economies. While the controversy about Three Wishes reminds us to accept the rights of the child to narrate her or his experience of war and violence, we also need to examine the modes of cultural production used to distinguish what is real and what is not and how such distinctions sanction complicities of innocence in national and transnational imaginaries. 